Article

\title{
Three Pairs of New Isopentenyl Dibenzo[b,e]oxepinone Enantiomers from Talaromyces flavus, a Wetland Soil-Derived Fungus
}

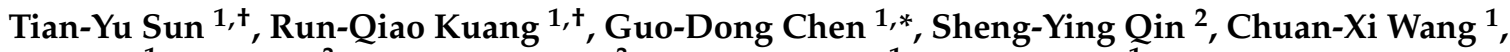 \\ Dan $\mathrm{Hu}^{1}$, Bing $\mathrm{Wu}^{3}$, Xing-Zhong Liu ${ }^{3}$, Xin-Sheng Yao ${ }^{1}$ and Hao Gao ${ }^{1, *}$ \\ 1 Institute of Traditional Chinese Medicine and Natural Products, College of Pharmacy, Jinan University, \\ Guangzhou 510632, China; sty4048588@163.com (T.-Y.S.); bridgekuang@163.com (R.-Q.K.); \\ wcxjnu@163.com (C.-X.W.); thudan@jnu.edu.cn (D.H.); tyaoxs@jnu.edu.cn (X.-S.Y.) \\ 2 Clinical Experimental Center, First Affiliated Hospital of Jinan University, Guangzhou 510632, China; \\ qinshengying78@163.com \\ 3 State Key Laboratory of Mycology, Institute of Microbiology, Chinese Academy of Sciences, Beijing 100190, \\ China; wubing@im.ac.cn (B.W.); liuxz@sun.im.ac.cn (X.-Z.L.) \\ * Correspondence: chgdtong@163.com (G.-D.C.); tghao@jnu.edu.cn (H.G.); \\ Tel./Fax: +86-20-8522-1559 (G.-D.C.); +86-20-8522-8369 (H.G.) \\ + These authors contributed equally to this work.
}

Academic Editors: Derek J. McPhee and Antigoni Kotali

Received: 12 August 2016; Accepted: 2 September 2016; Published: 7 September 2016

\begin{abstract}
Three pairs of new isopentenyl dibenzo[b,e]oxepinone enantiomers, $(+)-(5 S)$-arugosin $\mathrm{K}$ (1a), (-)-(5R)-arugosin K (1b), (+)-(5S)-arugosin L (2a), (-)-(5R)-arugosin L (2b), (+)-(5S)-arugosin M (3a), (-)-(5R)-arugosin $\mathrm{M}(3 \mathbf{b})$, and a new isopentenyl dibenzo[b,e]oxepinone, arugosin $\mathrm{N}(4)$, were isolated from a wetland soil-derived fungus Talaromyces flavus, along with two known biosyntheticallyrelated compounds 5 and 6 . Among them, arugosin N (4) and 1,6,10-trihydroxy-8-methyl-2-(3-methyl2-butenyl)-dibenz[b,e]oxepin-11(6H)-one (CAS: 160585-91-1, 5) were obtained as the tautomeric mixtures. The structures of isolated compounds were determined by detailed spectroscopic analysis. In addition, the absolute configurations of these three pairs of new enantiomers were determined by quantum chemical ECD calculations.
\end{abstract}

Keywords: isopentenyl dibenzo[b,e]oxepinone; wetland soil-derived fungus; Talaromyces flavus; arugosins $\mathrm{K}-\mathrm{N}$

\section{Introduction}

Isopentenyl dibenzo[b,e]oxepinones possess a dibenzo[b,e]oxepin-11(6H)-one skeleton (intact 6-7-6 tricyclic system) with isopentenyl substitution. Up to now, about nine isopentenyl dibenzo[b,e] oxepinones had been reported from fungi in Nature, including arugosins A-D from Aspergillus rugulosus $[1,2]$ and A. variecolor [3], arugosin G from Emericella nidulans var. acristata [4], pestalachloride B from Pestalotiopsis adusta [5], cephalanones D-E from Graphiopsis chlorocephala [6], and 1,6,10trihydroxy-8-methyl-2-(3-methyl-2-butenyl)-dibenz[b,e]oxepin-11(6H)-one (CAS: 160585-91-1, 5) from Penicilium sp. [7].

Talaromyces flavus, the commonest species of the genus Talaromyces, has been reported to produce a series of bioactive compounds $[8,9]$. In our search for bioactive secondary metabolites from wetland fungi [10-15], several interesting molecules also had been isolated from this species [12-15]. At present, a chemical investigation of metabolites from Talaromyces flavus AHK07-3 was carried out, which led to the isolation of three pairs of new isopentenyl dibenzo[b,e]oxepinone enantiomers $((+)-(5 S)$-arugosin $\mathrm{K}$ (1a), (-)-(5R)-arugosin K (1b), (+)-(5S)-arugosin L (2a), (-)-(5R)-arugosin L (2b), (+)-(5S)-arugosin M 
(3a), (-)-(5R)-arugosin M (3b)), a new isopentenyl dibenzo[b,e]oxepinone, arugosin $\mathrm{N}(4)$, and two known compounds 1,6,10-trihydroxy-8-methyl-2-(3-methyl-2-butenyl)-dibenz[b,e]oxepin-11(6H)-one (5) and chrysophanol (6) (Figure 1). The absolute configurations of the three pairs of enantiomers were determined by quantum chemical ECD calculations. In addition, arugosin N (4) and 1,6,10-trihydroxy8-methyl-2-(3-methyl-2-butenyl)-dibenz[b,e]oxepin-11(6H)-one (5) were a pair of tautomers, and they were isolated as mixtures. Detail of the isolation and structural elucidations of compounds 1-6 are presented herein.

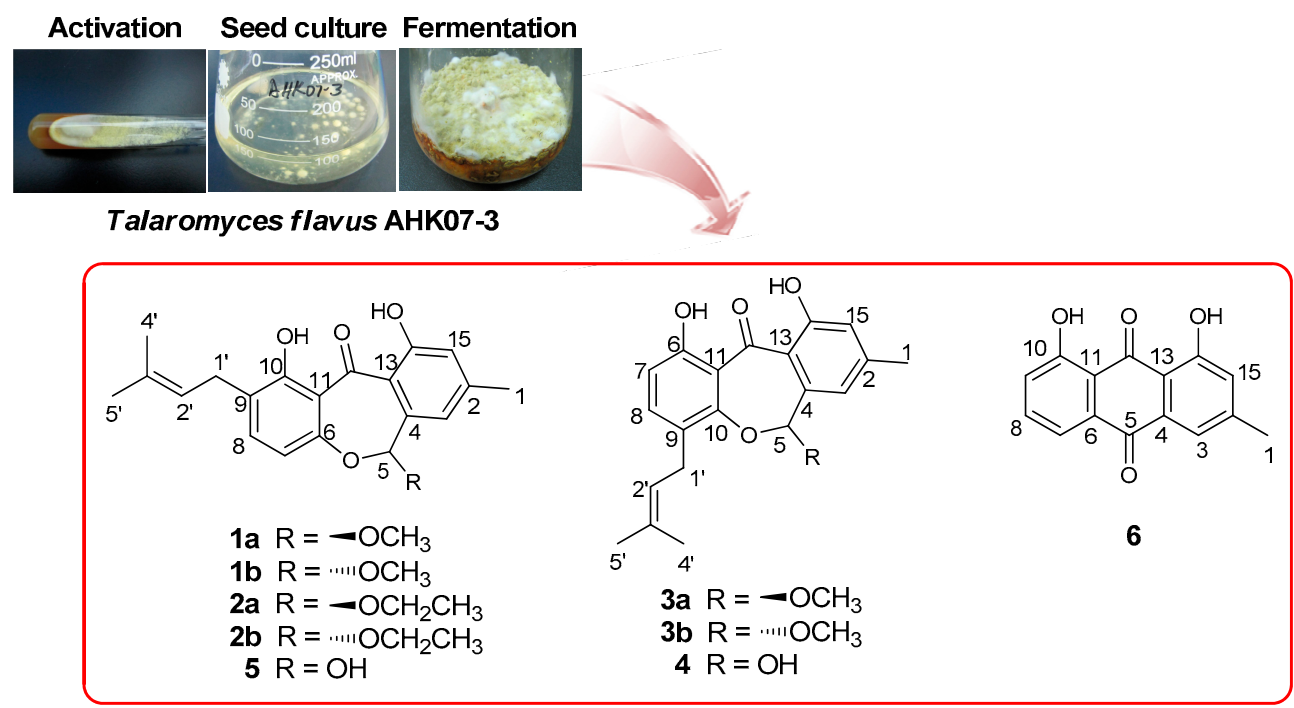

Figure 1. Production and chemical structures of 1-6.

\section{Results and Discussion}

Compound 1 was obtained as a yellow solid. The quasi-molecular ion at $m / z 355.1550[\mathrm{M}+\mathrm{H}]^{+}$ obtained by HRESIMS indicated the molecular formula of 1 was $\mathrm{C}_{21} \mathrm{H}_{22} \mathrm{O}_{5}$ with 11 degrees of unsaturation. The ${ }^{13} \mathrm{C}-\mathrm{NMR}$ spectrum combined with the DEPT-135 spectrum showed 21 signals (Table 1), assigned to ten $\mathrm{sp}^{2}$ quaternary carbons [including one ketone carbonyl $\left(\delta_{\mathrm{C}} 197.5\right)$, nine aromatic/olefinic carbons $\left(\delta_{C} 162.8,162.4,154.5,147.1,138.5,133.2,124.8,116.8\right.$, and 113.6), five sp ${ }^{2}$ methine carbons $\left(\delta_{C} 137.6,121.8,119.5,116.8\right.$, and 109.3$)$, one $\mathrm{sp}^{3}$ oxygenated methine carbon $\left(\delta_{C} 103.4\right)$, one $\mathrm{sp}^{3}$ methylene carbon $\left(\delta_{C} 27.8\right)$, and four methyl carbons $\left(\delta_{C} 56.9,25.8,21.8\right.$, and 17.8$)$. In the ${ }^{1} \mathrm{H}-\mathrm{NMR}$ spectrum of $\mathbf{1}$ (Table 1$)$, the characteristic signals of two exchangeable protons $\left(\delta_{\mathrm{H}} 13.62(1 \mathrm{H}, \mathrm{s})\right.$ and $11.46(1 \mathrm{H}, \mathrm{s}))$, five aromatic or olefinic protons $\left(\delta_{\mathrm{H}} 7.33(1 \mathrm{H}, \mathrm{d}, J=8.3 \mathrm{~Hz}), 6.94(1 \mathrm{H}, \mathrm{s}), 6.87(1 \mathrm{H}, \mathrm{s})\right.$, $6.58(1 \mathrm{H}, \mathrm{d}, J=8.3 \mathrm{~Hz})$, and $5.33(1 \mathrm{H}, \mathrm{br} \mathrm{t}, J=7.3 \mathrm{~Hz})$, one $\mathrm{sp}^{3}$ oxygenated methine proton $\left(\delta_{\mathrm{H}} 5.64(1 \mathrm{H}\right.$, $\mathrm{s})$ ), one $\mathrm{sp}^{3}$ methylene $\left(\delta_{\mathrm{H}} 3.34(2 \mathrm{H}, \mathrm{d}, J=7.3 \mathrm{~Hz})\right)$, and four methyl protons $\left(\delta_{\mathrm{H}} 3.57(3 \mathrm{H}, \mathrm{s}), 2.37(3 \mathrm{H}\right.$, s), $1.77(3 \mathrm{H}, \mathrm{br} \mathrm{s})$, and $1.73(3 \mathrm{H}, \mathrm{br} \mathrm{s}))$ were observed. The non-exchangeable proton resonances were associated with the directly attached carbon atoms in the HSQC experiment (Table 1). The analysis of the ${ }^{1} \mathrm{H}_{-}{ }^{1} \mathrm{H}$ COSY experiment and the coupling values of the protons indicated the presence of two subunits (C-7-C-8 and C-1'-C-2') as shown in Figure 2. Combined with the analysis of the ${ }^{1} \mathrm{H}-{ }^{1} \mathrm{H}$ COSY experiment and molecular formula, the HMBC correlations from $\mathrm{H}_{3}-1$ to C-2/C-3/C-15, from H-3 to C-1/C-5/C-13/C-15, from H-5 to C-3/C-6/C-13/5-OC H $_{3}$, from H-7 to C-6/C-9/C-11, from H-8 to $\mathrm{C}-6 / \mathrm{C}-10$, from $\mathrm{H}_{2}-1^{\prime}$ to $\mathrm{C}-8 / \mathrm{C}-9 / \mathrm{C}-10$, from $\mathrm{H}_{3}-4^{\prime}$ to $\mathrm{C}-2^{\prime} / \mathrm{C}-3^{\prime} / \mathrm{C}-5^{\prime}$, from $\mathrm{H}_{3}-5^{\prime}$ to $\mathrm{C}-2^{\prime} / \mathrm{C}-3^{\prime} / \mathrm{C}-4^{\prime}$, from $5-\mathrm{OCH}_{3}$ to $\mathrm{C}-5$, from $10-\mathrm{O} \underline{\mathrm{H}}$ to $\mathrm{C}-9 / \mathrm{C}-10 / \mathrm{C}-11$, and from $14-\mathrm{OH}$ to $\mathrm{C}-13 / \mathrm{C}-14 / \mathrm{C}-15$ revealed the planer structure of $\mathbf{1}$ (Figure 2). On the basis of the above analyses, the planar structure of $\mathbf{1}$ (Figure 2) was established, and it was named arugosin $\mathrm{K}$. The assignments of all proton and carbon resonances are provided in Table 1. 
Table 1. The ${ }^{13} \mathrm{C}$ - and ${ }^{1} \mathrm{H}-\mathrm{NMR}$ data of $\mathbf{1 - 3}$ ( $\delta$ in ppm, $J$ in $\mathrm{Hz}$ ).

\begin{tabular}{|c|c|c|c|c|c|c|c|c|}
\hline \multicolumn{3}{|c|}{$1^{a}$} & \multicolumn{3}{|c|}{$2^{b}$} & \multicolumn{3}{|c|}{$3^{a}$} \\
\hline No. & $\delta_{C}$ & $\delta_{\mathbf{H}}$ & No. & $\delta_{C}$ & $\delta_{H}^{c}$ & No. & $\delta_{C}$ & $\delta_{H}^{c}$ \\
\hline 1 & 21.8 & $2.37, \mathrm{~s}$ & 1 & 21.9 & $2.38, \mathrm{~s}$ & 1 & 21.9 & $2.39, \mathrm{~s}$ \\
\hline 2 & 147.1 & & 2 & 147.2 & & 2 & 147.1 & \\
\hline 3 & 116.8 & $6.94, \mathrm{~s}$ & 3 & 116.8 & $6.98, \mathrm{~s}$ & 3 & 116.6 & $6.97, \mathrm{~s}$ \\
\hline 4 & 138.5 & & 4 & 138.8 & & 4 & 138.3 & \\
\hline 5 & 103.4 & $5.64, \mathrm{~s}$ & 5 & 102.0 & $5.74, \mathrm{~s}$ & 5 & 103.9 & $5.71, \mathrm{~s}$ \\
\hline 6 & 154.5 & & 6 & 154.8 & & 6 & 163.5 & \\
\hline 7 & 109.3 & $6.58, \mathrm{~d}(8.3)$ & 7 & 109.3 & $6.55, \mathrm{~d}(8.3)$ & 7 & 112.2 & $6.70, \mathrm{~d}(8.5)$ \\
\hline 8 & 137.6 & 7.33, d (8.3) & 8 & 137.6 & $7.32, \mathrm{~d}(8.3)$ & 8 & 138.4 & 7.35, d (8.5) \\
\hline 9 & 124.8 & & 9 & 124.7 & & 9 & 121.8 & \\
\hline 10 & 162.8 & & 10 & 162.7 & & 10 & 153.2 & \\
\hline 11 & 113.6 & & 11 & 113.7 & & 11 & 113.9 & \\
\hline 12 & 197.5 & & 12 & 197.6 & & 12 & 197.5 & \\
\hline 13 & 116.8 & & 13 & 116.9 & & 13 & 117.0 & \\
\hline 14 & 162.4 & & 14 & 162.3 & & 14 & 161.9 & \\
\hline 15 & 119.5 & $6.87, \mathrm{~s}$ & 15 & 119.4 & $6.86, \mathrm{~s}$ & 15 & 119.4 & $6.87, \mathrm{~s}$ \\
\hline $1^{\prime}$ & 27.8 & $3.34, \mathrm{~d}(7.3)$ & $1^{\prime}$ & 27.8 & $\begin{array}{l}3.35 \text {, dd }(15.9,7.4), \mathrm{a} \\
3.31, \mathrm{dd}(15.9,7.4), \mathrm{b}\end{array}$ & $1^{\prime}$ & 28.0 & $\begin{array}{l}3.36, \mathrm{dd}(15.6,7.5), \mathrm{a} \\
3.30, \mathrm{dd}(15.6,7.5), \mathrm{b}\end{array}$ \\
\hline $2^{\prime}$ & 121.8 & 5.33, br t $(7.3)$ & $2^{\prime}$ & 121.8 & 5.32 & $2^{\prime}$ & 122.1 & 5.25 \\
\hline $3^{\prime}$ & 133.2 & & $3^{\prime}$ & 133.3 & & $3^{\prime}$ & 133.2 & \\
\hline $4^{\prime}$ & 25.8 & 1.77 , br s & $4^{\prime}$ & 25.8 & 1.76, br s & $4^{\prime}$ & 25.7 & 1.73, br s \\
\hline $5^{\prime}$ & 17.8 & 1.73, br s & $5^{\prime}$ & 17.8 & 1.73, br s & $5^{\prime}$ & 17.8 & 1.71 , br s \\
\hline $5-\mathrm{OCH}_{3}$ & 56.9 & $3.57, \mathrm{~s}$ & $1^{\prime \prime}$ & 65.3 & $\begin{array}{l}\text { 3.96, dq }(9.6,7.1), \mathrm{a} \\
\text { 3.66, dq }(9.6,7.1), \mathrm{b}\end{array}$ & $5-\mathrm{OCH}_{3}$ & 57.3 & $3.57, \mathrm{~s}$ \\
\hline & & & $2^{\prime \prime}$ & 14.8 & $1.26, \mathrm{t}(7.1)$ & & & \\
\hline $10-\mathrm{OH}$ & & $13.62, \mathrm{~s}$ & $10-\mathrm{OH}$ & & $13.63, \mathrm{~s}$ & $6-\mathrm{OH}$ & & $13.14, \mathrm{~s}$ \\
\hline $14-\mathrm{OH}$ & & $11.46, \mathrm{~s}$ & $14-\mathrm{OH}$ & & $11.44, \mathrm{~s}$ & $14-\mathrm{OH}$ & & $11.22, \mathrm{~s}$ \\
\hline
\end{tabular}

${ }^{a}$ The data recorded in $\mathrm{CDCl}_{3}\left({ }^{1} \mathrm{H}-\mathrm{NMR}\right.$ for $400 \mathrm{MHz},{ }^{13} \mathrm{C}-\mathrm{NMR}$ for $\left.100 \mathrm{MHz}\right) ;{ }^{\mathrm{b}}$ The data recorded in $\mathrm{CDCl}{ }_{3}\left({ }^{1} \mathrm{H}-\mathrm{NMR}\right.$ for $600 \mathrm{MHz},{ }^{13} \mathrm{C}-\mathrm{NMR}$ for $\left.150 \mathrm{MHz}\right) ;{ }^{\mathrm{c}}$ Indiscernible signals owing to overlapping or having complex multiplicity are reported without designating multiplicity. The letters of a and $\mathrm{b}$ mean that these two potons on $\mathrm{C}-1^{\prime}$ are not chemical equivalence. 


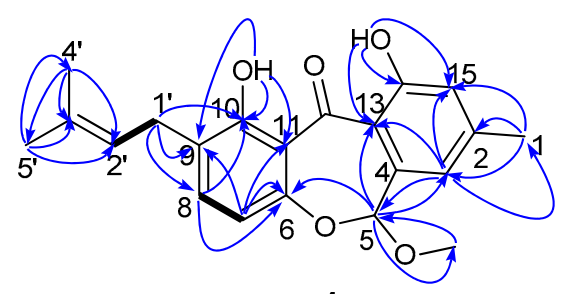

1

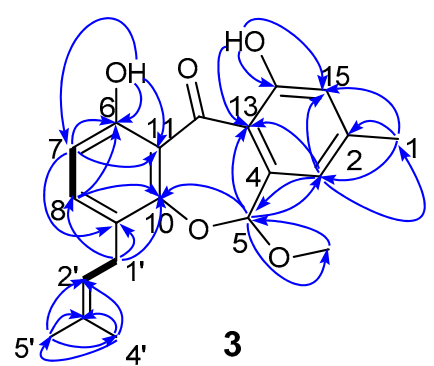

3

- ${ }^{1} \mathrm{H}-{ }^{1} \mathrm{H}$ COSY

$\frown \mathrm{HMBC}$

Figure 2. Key ${ }^{1} \mathrm{H}_{-}{ }^{1} \mathrm{H}$ COSY and $\mathrm{HMBC}$ correlations of $\mathbf{1}$ and 3.

The specific rotation value of $\mathbf{1}$ was close to zero, indicating that $\mathbf{1}$ was a racemic mixture. Compound 1 displayed two peaks in a Phenomenex Lux Cellulose-2 chiral column (Figure 3), which confirmed the above deduction. Therefore, $(+)-\mathbf{1 a}\left(t_{\mathrm{R}}=20.3 \mathrm{~min}\right)$ and $(-)-\mathbf{1} \mathbf{b}\left(t_{\mathrm{R}}=23.2 \mathrm{~min}\right)$ were isolated from 1 by a Phenomenex Lux Cellulose- 2 chiral column using $\mathrm{CH}_{3} \mathrm{OH} / \mathrm{H}_{2} \mathrm{O}(88 / 12, v / v)$ as eluent at a flow rate of $0.7 \mathrm{~mL} / \mathrm{min}$. The ECD spectra and $[\alpha]_{\mathrm{D}}$ values of $\mathbf{1 a}\left([\alpha]_{\mathrm{D}}^{27}+27.8\left(c 0.5, \mathrm{CHCl}_{3}\right)\right)$ and $\mathbf{1 b}\left([\alpha]_{\mathrm{D}}^{27}-27.0\left(c 0.5, \mathrm{CHCl}_{3}\right)\right)$ showed their enantiomeric relationship.

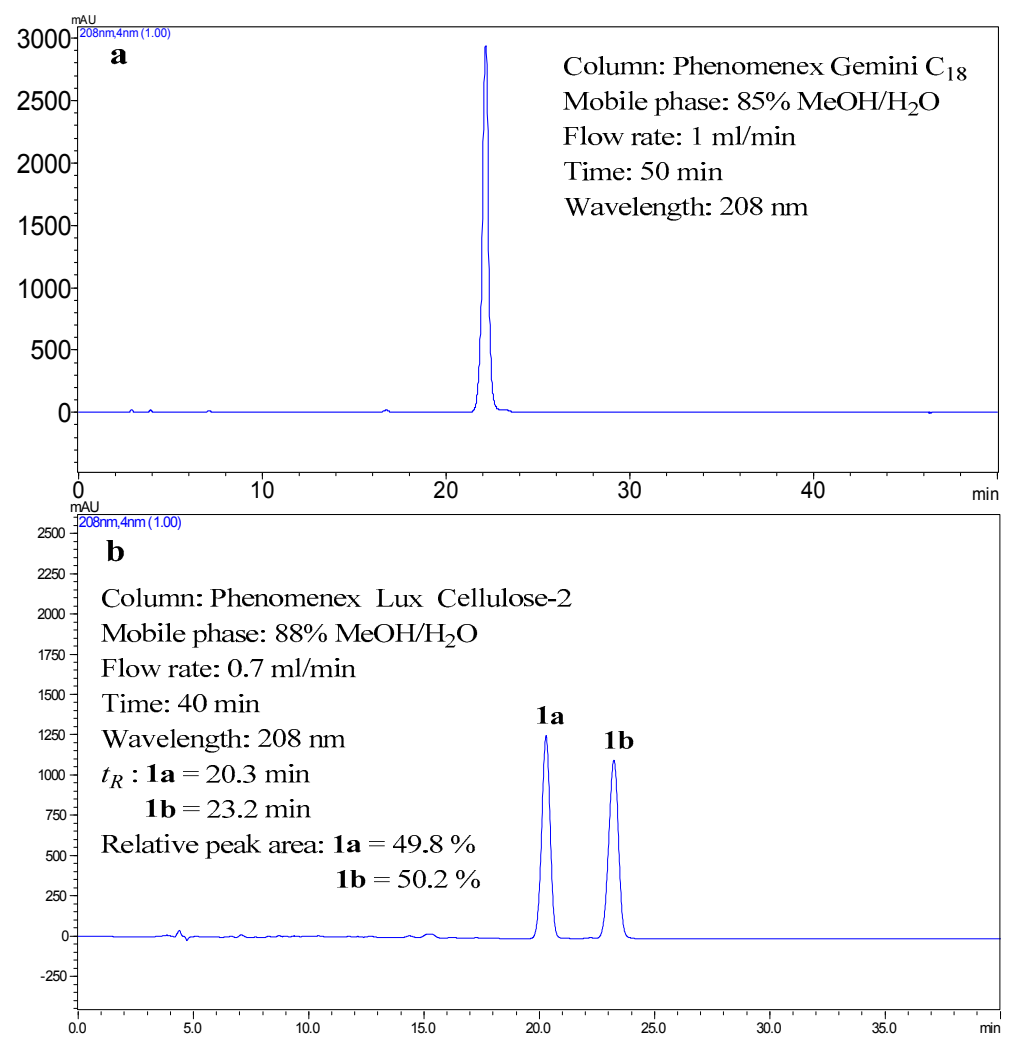

Figure 3. HPLC analysis of $\mathbf{1}$. a: the analysis of $\mathbf{1}$ on routine ODS HPLC; $\mathbf{b}$ : the analysis of $\mathbf{1}$ on chiral HPLC.

The absolute configurations of $\mathbf{1 a}$ and $\mathbf{1 b}$ were determined by quantum chemical ECD calculations at the APFD/6-311++G(2d,p) level. The predicted ECD curves of (5S)-1 and (5R)-1 (Figure 4) were in good accordance with the experimental ECD for $\mathbf{1 a}$ and $\mathbf{1} \mathbf{b}$, respectively. Therefore, the absolute configurations of $\mathbf{1} \mathbf{a}$ and $\mathbf{1} \mathbf{b}$ were identified as $5 S$ and $5 R$, respectively. 


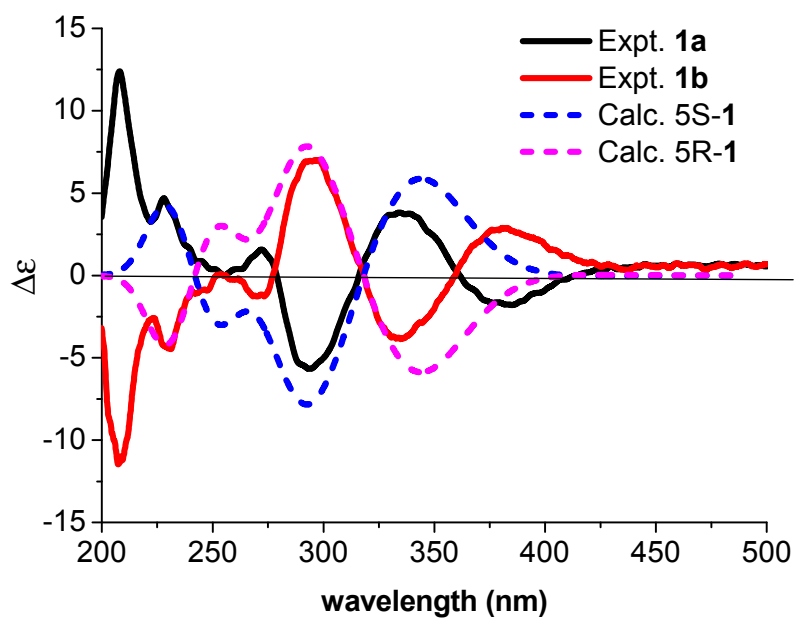

Figure 4. The experimental ECD spectra of $\mathbf{1 a}$ and $\mathbf{1 b}$ and calculated ECD spectra for (5S)-1 and (5R)-1 (UV correction $=-10 \mathrm{~nm}$, band width $\sigma=0.3 \mathrm{eV}$ ).

Compound 2 was obtained as a yellow solid. The quasi-molecular ion at $m / z 369.1695[\mathrm{M}+\mathrm{H}]^{+}$ by HRESIMS indicated the molecular formula of 2 was $\mathrm{C}_{22} \mathrm{H}_{24} \mathrm{O}_{5}$ with 11 degrees of unsaturation. Except for the loss of an oxygenated methyl at $\delta_{\mathrm{C}} 56.9\left(5-\mathrm{OCH}_{3}\right)$ and the appearance of an additional oxygenated methylene at $\delta_{\mathrm{C}} 65.3\left(\mathrm{C}-1^{\prime \prime}\right)$ and methyl at $\delta_{\mathrm{C}} 14.8\left(\mathrm{C}-2^{\prime \prime}\right)$, the NMR data of 2 (Table 1$)$ were similar to those of $\mathbf{1}$ (Table 1), which indicated that the $5-\mathrm{OCH}_{3}$ in $\mathbf{1}$ was replaced by $5-\mathrm{OCH}_{2} \mathrm{CH}_{3}$ in $\mathbf{2}$. This deduction was supported by the ${ }^{1} \mathrm{H}_{-}{ }^{1} \mathrm{H}$ COSY correlations of $\mathrm{Ha}-1^{\prime \prime} / \mathrm{Hb}-1^{\prime \prime}$ and $\mathrm{H}_{3}-2^{\prime \prime}$ and the key HMBC correlations from $\mathrm{H}-5$ to $\mathrm{C}-1^{\prime \prime}$, from $\mathrm{Ha}-1^{\prime \prime} / \mathrm{Hb}-1^{\prime \prime}$ to $\mathrm{C}-5 / \mathrm{C}-2^{\prime \prime}$, and from $\mathrm{H}_{3}-2^{\prime \prime}$ to $\mathrm{C}-1^{\prime \prime}$. On the basis of the exhaustive analysis of 2D NMR data $\left({ }^{1} \mathrm{H}_{-}{ }^{1} \mathrm{H}\right.$ COSY, HSQC, and HMBC) (Table S2, Supplementary Materials), the planar structure of 2, named arugosin L, was established (Figure 1).

Since 1 and 2 coexist in the same strain, 2 was also a racemic mixture, and it displayed two peaks in a Phenomenex Lux Cellulose-2 chiral column (Figure S1, Supplementary Materials). Therefore, $(+)-\mathbf{2} \mathbf{a}\left(t_{\mathrm{R}}=22.6 \mathrm{~min}\right)$ and $(-)-\mathbf{2} \mathbf{b}\left(t_{\mathrm{R}}=26.6 \mathrm{~min}\right)$ were isolated from $\mathbf{2}$ by a Phenomenex Lux Cellulose- 2 chiral column using $\mathrm{CH}_{3} \mathrm{OH} / \mathrm{H}_{2} \mathrm{O}(88 / 12, v / v)$ as eluent at a flow rate of $0.7 \mathrm{~mL} / \mathrm{min}$. The ECD spectra and $[\alpha]_{\mathrm{D}}$ values of $2 \mathbf{a}\left([\alpha]_{\mathrm{D}}^{27}+27.4\left(c 0.5, \mathrm{CHCl}_{3}\right)\right)$ and $\mathbf{2 b}\left([\alpha]_{\mathrm{D}}^{27}-26.8\left(c 0.5, \mathrm{CHCl}_{3}\right)\right)$ showed their enantiomeric relationship. Since the ECD data of 2a were similar to that of 1a (Figure 5), the absolute configuration of $\mathbf{2} \mathbf{a}$ was determined as $5 S$ (Figure 5). The similar observation was found between $\mathbf{2 b}$ and $\mathbf{1 b}$. Therefore, the absolute configurations of $\mathbf{2} \mathbf{a}$ and $\mathbf{2} \mathbf{b}$ were assigned as $5 S$ and $5 R$, respectively.

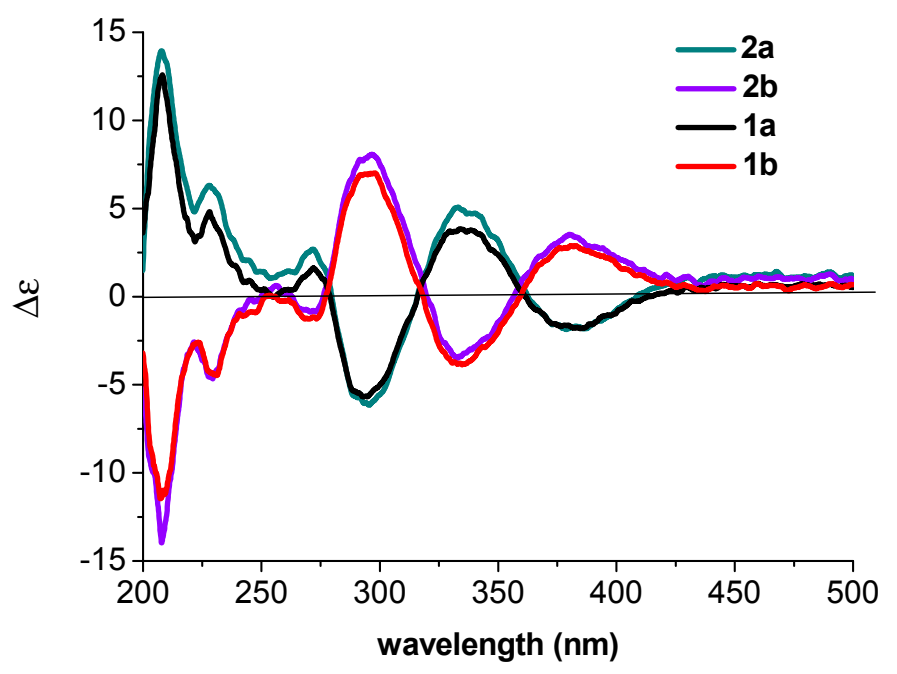

Figure 5. The experimental ECD spectra of $\mathbf{2 a}, \mathbf{2} \mathbf{b}, \mathbf{1} \mathbf{a}$, and $\mathbf{1} \mathbf{b}$. 
Compound 3 was obtained as a yellow solid. The quasi-molecular ion at $m / z 355.1541[\mathrm{M}+\mathrm{H}]^{+}$ by HRESIMS indicated the molecular formula of 3 was $\mathrm{C}_{21} \mathrm{H}_{22} \mathrm{O}_{5}$ with 11 degrees of unsaturation, which indicated that 3 was the isomer of $\mathbf{1}$. Furthermore, the NMR data of $\mathbf{3}$ (Table 1) were similar to those of $\mathbf{1}$, which suggested that 3 and $\mathbf{1}$ had the similar skeleton. The analysis of the ${ }^{1} \mathrm{H}-{ }^{1} \mathrm{H}$ COSY experiment and the coupling values of the protons indicated the presence of two subunits (C-7-C-8 and C-1'-C-2') as shown in Figure 2. Combined with the analysis of the ${ }^{1} \mathrm{H}-{ }^{1} \mathrm{H}$ COSY experiment and molecular formula, the $\mathrm{HMBC}$ correlations (Figure 2) from $\mathrm{H}_{3}-1$ to $\mathrm{C}-2 / \mathrm{C}-3 / \mathrm{C}-15$, from $\mathrm{H}-3$ to $\mathrm{C}-1 / \mathrm{C}-5 / \mathrm{C}-13 / \mathrm{C}-15$, from $\mathrm{H}-5$ to $\mathrm{C}-3 / \mathrm{C}-10 / \mathrm{C}-13 / 5-\mathrm{OCH}_{3}$, from $\mathrm{H}-7$ to $\mathrm{C}-6 / \mathrm{C}-9 / \mathrm{C}-11$, from $\mathrm{H}-8$ to $\mathrm{C}-6 / \mathrm{C}-10$, from $\mathrm{Ha}-\mathrm{1}^{\prime} / \mathrm{Hb}-\mathrm{1}^{\prime}$ to $\mathrm{C}-8 / \mathrm{C}-9 / \mathrm{C}-10$, from $\mathrm{H}_{3}-4^{\prime}$ to $\mathrm{C}-2^{\prime} / \mathrm{C}-3^{\prime} / \mathrm{C}-5^{\prime}$, from $\mathrm{H}_{3}-5^{\prime}$ to $\mathrm{C}-2^{\prime} / \mathrm{C}-3^{\prime} / \mathrm{C}-4^{\prime}$, from $5-\mathrm{OC} \underline{H}_{3}$ to C-5, from $6-\mathrm{OH}$ to C-6/C-7/C-11, and from $14-\mathrm{OH}$ to C-13/C-14/C-15 confirmed the planar structure of 3 , which is named arugosin $\mathrm{M}$.

Since 1 and $\mathbf{3}$ coexist in the same strain, $\mathbf{3}$ was also a racemic mixture, and it displayed two peaks in a Phenomenex Lux Cellulose-2 chiral column (Figure S2, Supplementary Materials). Therefore, $(+)-3 \mathbf{a}\left(t_{\mathrm{R}}=20.4 \mathrm{~min}\right)$ and $(-)-3 \mathbf{b}\left(t_{\mathrm{R}}=22.1 \mathrm{~min}\right)$ were isolated from $\mathbf{3}$ by a Phenomenex Lux Cellulose- 2 chiral column using $\mathrm{CH}_{3} \mathrm{OH} / \mathrm{H}_{2} \mathrm{O}(88 / 12, v / v)$ as eluent at a flow rate of $0.7 \mathrm{~mL} / \mathrm{min}$. The ECD spectra and $[\alpha]_{\mathrm{D}}$ values of $\mathbf{3 a}\left([\alpha]_{\mathrm{D}}^{27}+28.4\left(c 0.5, \mathrm{CHCl}_{3}\right)\right)$ and $\mathbf{3 b}\left([\alpha]_{\mathrm{D}}^{27}-27.6\left(c 0.5, \mathrm{CHCl}_{3}\right)\right)$ showed their enantiomeric relationship. The absolute configurations of $\mathbf{3 a}$ and $\mathbf{3 b}$ were determined by quantum chemical ECD calculations at the APFD/6-311++g(2d,p) level. The predicted ECD curves of (5S)-3 and (5R)-3 were in good accordance with the experimental ECD for $\mathbf{3} \mathbf{a}$ and $\mathbf{3} \mathbf{b}$, respectively (Figure 6). Therefore, the absolute configurations of $\mathbf{3} \mathbf{a}$ and $\mathbf{3} \mathbf{b}$ were identified as $5 S$ and $5 R$, respectively.

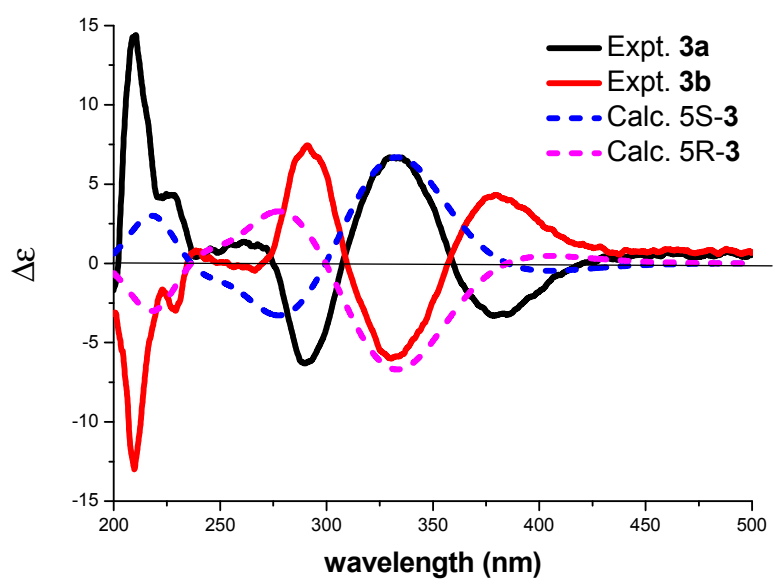

Figure 6. The experimental ECD spectra of $\mathbf{3} \mathbf{a}$ and $\mathbf{3} \mathbf{b}$ and calculated ECD spectra for (5S)-3 and (5R)-3 (UV correction $=-20 \mathrm{~nm}$, band width $\sigma=0.3 \mathrm{eV})$.

Compounds 4 and 5 were obtained as mixtures of yellow solids. The quasi-molecular ion at $m / z 363.1213[\mathrm{M}+\mathrm{Na}]^{+}$by HRESIMS indicated the molecular formulas of 4 and $\mathbf{5}$ were $\mathrm{C}_{20} \mathrm{H}_{20} \mathrm{O}_{5}$, with 11 degrees of unsaturation. The NMR data of the mixtures presented two sets of signals, assigned to 4 and 5 respectively (Table 2). The molecular formula of 4 was fourteen atomic mass units less than 3. Except for the loss of an oxygenated methyl at $\delta_{\mathrm{C}} 57.3\left(5-\mathrm{OCH}_{3}\right)$, the ${ }^{1} \mathrm{H}$ NMR and ${ }^{13} \mathrm{C}-\mathrm{NMR}$ data of 4 (Table 2) were similar to those of 3 (Table 1), which indicated that the $5-\mathrm{OCH}_{3}$ in 3 was replaced by the hydroxyl in 4 . On the basis of the exhaustive analysis of $2 \mathrm{D}$ NMR data $\left({ }^{1} \mathrm{H}^{-1} \mathrm{H}\right.$ COSY, HSQC, and HMBC) (Table S4, Supplementary Materials), the planar structure of 4 was established, named $\operatorname{arugosin} \mathrm{N}$.

The molecular formula of 5 was fourteen atomic mass units less than 1. Except for the loss of an oxygenated methyl at $\delta_{\mathrm{C}} 56.9\left(5-\mathrm{OCH}_{3}\right)$, the ${ }^{1} \mathrm{H}-\mathrm{NMR}$ and ${ }^{13} \mathrm{C}-\mathrm{NMR}$ data of 5 (Table 2) were similar to those of $\mathbf{1}$ (Table 1), which indicated that the $5-\mathrm{OCH}_{3}$ in $\mathbf{1}$ was replaced by the hydroxyl in 5. On the basis of the exhaustive analysis of $2 \mathrm{D}$ NMR data $\left({ }^{1} \mathrm{H}-{ }^{1} \mathrm{H}\right.$ COSY, HSQC, and HMBC) (Table S5, Supplementary Materials), the planar structure of 5 was established as the known compound, 1,6,10-trihydroxy-8-methyl-2-(3-methyl-2-butenyl)-dibenz[b,e]oxepin-11(6H)-one [7]. 
Table 2. The ${ }^{1} \mathrm{H}-\mathrm{NMR}$ and ${ }^{13} \mathrm{C}-\mathrm{NMR}$ data of 4 and 5 ( $\delta$ in ppm, $J$ in $\mathrm{Hz}$ ).

\begin{tabular}{cccccc}
\hline \multicolumn{2}{c}{$\mathbf{4}^{\mathbf{a}}$} & \multicolumn{3}{c}{$\mathbf{5}^{\mathbf{a}}$} \\
\hline No. & $\boldsymbol{\delta}_{\mathbf{C}}$ & $\boldsymbol{\delta}_{\mathbf{H}}$ & No. & $\boldsymbol{\delta}_{\mathbf{C}}$ & $\boldsymbol{\delta}_{\mathbf{H}}$ \\
\hline 1 & 22.0 & $2.40, \mathrm{~s}$ & 1 & 21.9 & $2.40, \mathrm{~s}$ \\
2 & 147.6 & & 2 & 147.4 & \\
3 & 116.0 & $7.07, \mathrm{~s}$ & 3 & 116.2 & $7.04, \mathrm{~s}$ \\
4 & 139.7 & & 4 & 139.3 & \\
5 & 97.1 & $6.11, \mathrm{~s}$ & 5 & 96.6 & $6.12, \mathrm{~s}$ \\
6 & 163.6 & & 6 & 154.5 & \\
7 & 112.9 & $6.71, \mathrm{~d}(8.4)$ & 7 & 109.6 & $6.53, \mathrm{~d}(8.4)$ \\
8 & 138.5 & $7.34, \mathrm{~d}(8.4)$ & 8 & 137.7 & $7.32, \mathrm{~d}(8.4)$ \\
9 & 122.4 & & 9 & 125.1 & \\
10 & 154.0 & & 10 & 162.9 & \\
11 & 114.6 & & 11 & 113.5 & \\
12 & 197.3 & & 12 & 197.3 & \\
13 & 116.5 & & 13 & 116.7 & \\
14 & 163.3 & & 14 & 162.7 & \\
15 & 119.8 & $6.89, \mathrm{~s}$ & 15 & 119.7 & $6.89, \mathrm{~s}$ \\
$1^{\prime}$ & 28.9 & $3.36, \mathrm{dd}(15.4,7.2), \mathrm{a}$ & $1^{\prime}$ & 27.8 & $3.33, \mathrm{~d}(7.5)$ \\
& & $3.22, \mathrm{dd}(15.4,7.2), \mathrm{b}$ & & & \\
$2^{\prime}$ & 123.1 & $5.24, \mathrm{br} \mathrm{t}(7.2)$ & $2^{\prime}$ & 121.7 & $5.31, \mathrm{br} \mathrm{t}(7.5)$ \\
$3^{\prime}$ & 133.0 & & $3^{\prime}$ & 133.4 & \\
$4^{\prime}$ & 25.7 & $1.76, \mathrm{~s}$ & $4^{\prime}$ & 25.8 & $1.76, \mathrm{~s}$ \\
$5^{\prime}$ & 18.0 & $1.74, \mathrm{~s}$ & $5^{\prime}$ & 17.8 & $1.72, \mathrm{~s}$ \\
$6-\mathrm{OH}$ & & $12.95, \mathrm{br} \mathrm{s}$ & $10-\mathrm{OH}$ & & $13.61, \mathrm{br} \mathrm{s}$ \\
$14-\mathrm{OH}$ & & $11.82, \mathrm{br} \mathrm{s}$ & $14-\mathrm{OH}$ & & $11.54, \mathrm{br} \mathrm{s}$ \\
\hline
\end{tabular}

a The data recorded in $\mathrm{CDCl}_{3}\left({ }^{1} \mathrm{H}-\mathrm{NMR}\right.$ for $400 \mathrm{MHz},{ }^{13} \mathrm{C}-\mathrm{NMR}$ for $\left.100 \mathrm{MHz}\right)$. The letters of a and b mean that these two potons on $\mathrm{C}-1^{\prime}$ are not chemical equivalence.

The C-5 positions of 4 and 5 were hemiacetal linkage, which were unstable and easy to split. Therefore, $\mathbf{4}$ and 5 can self-interconvert (Figure 7) and exist as inseparable tautomeric mixtures in Nature.

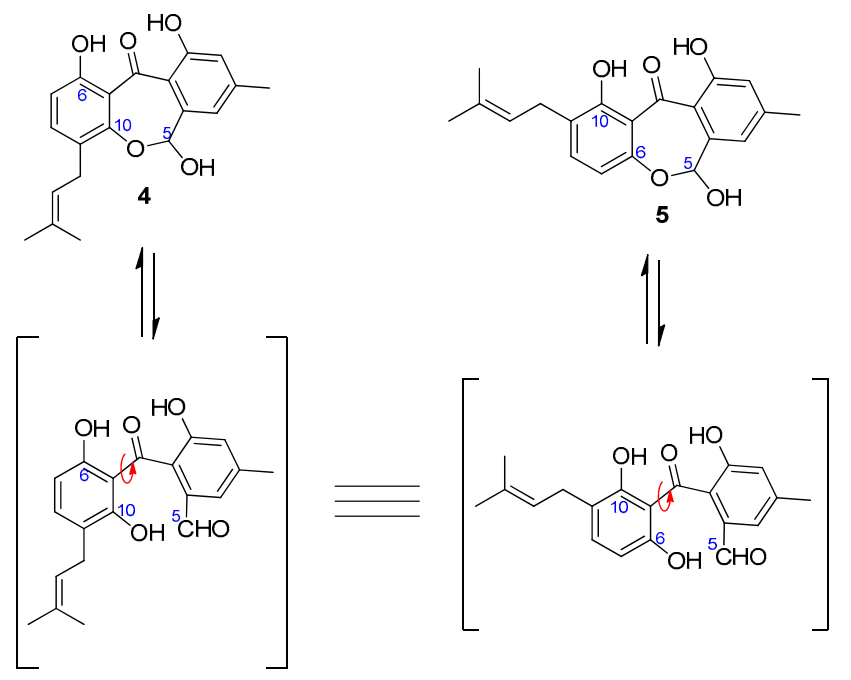

Figure 7. The interconversion of 4 and 5.

Compound 6 was obtained as a yellow solid. The ESI-MS (positive): $m / z 255[\mathrm{M}+\mathrm{H}]^{+}$; ESI-MS (negative): $m / z 253[\mathrm{M}-\mathrm{H}]^{-}$indicated the molecular weight was 254 . It was identified as chrysophanol by comparing its data $\left({ }^{1} \mathrm{H}-\right.$ and $\left.{ }^{13} \mathrm{C}-\mathrm{NMR}, \mathrm{MS}\right)$ with literature values [16]. 
Based on the structural features of compounds 1-6 and literature investigation, a plausible biosynthetic pathway of them was proposed (Scheme 1). Chrysophanol (6) undergoes oxidization [17,18], ring-cleavage [17,18], reduction [17,18], and isoprentenylation to yield arugosin I [17], which may be the precursor of arugosin N (4) and 1,6,10-trihydroxy-8-methyl-2-(3-methyl-2-butenyl)-dibenz[b,e]oxepin11(6H)-one (5). Then, arugosin K (1) and arugosin L (2) may originate from 5 by methylation and ethylation, respectively. Arugosin M (3) may originate from 4 by methylation.

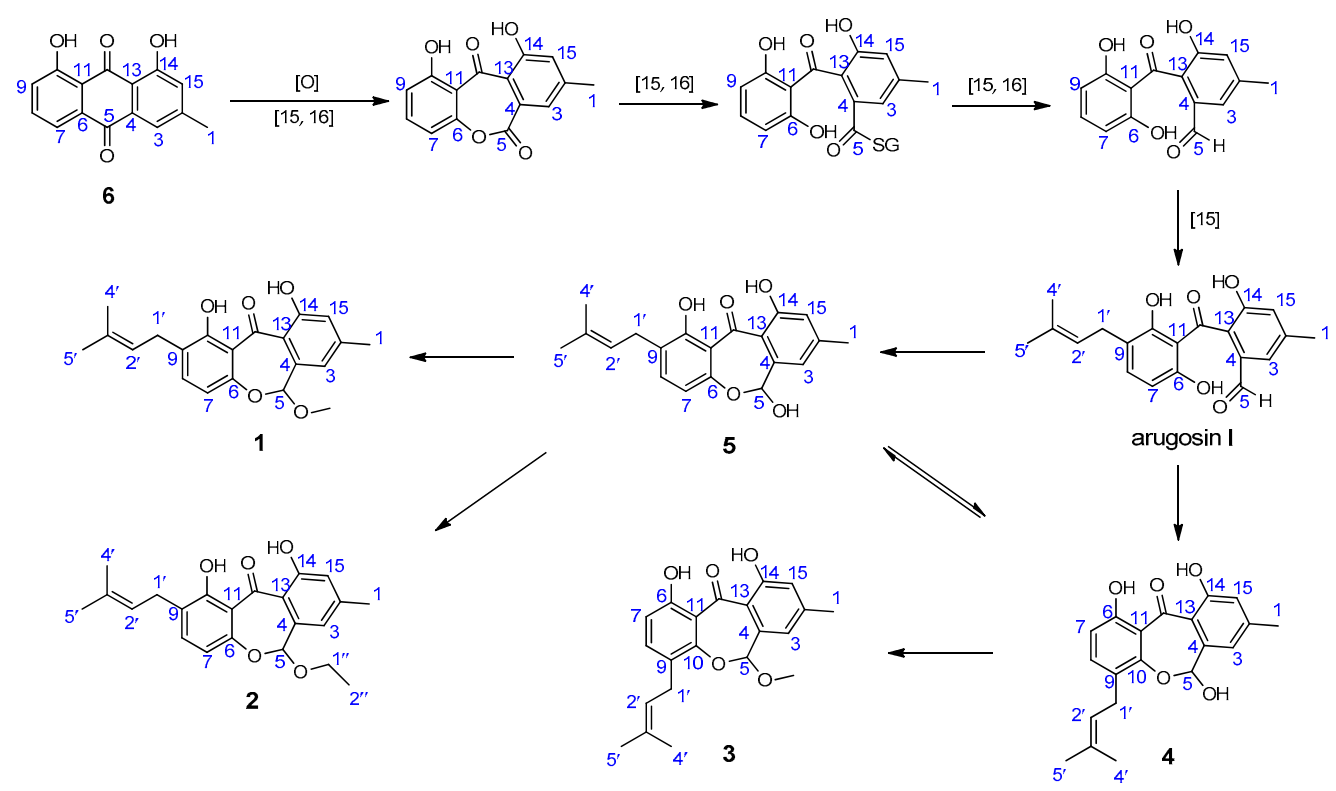

Scheme 1. The plausible biosynthetic pathways of 1-6.

\section{Materials and Methods}

\subsection{Chemicals}

Methanol (MeOH) was purchased from Yuwang Industrial Co. Ltd. (Yucheng, China). Cyclohexane, ethyl acetate (EtOAc), and petroleum ether (PE) were purchased from Tianjin Fuyu Fine Chemical Co. Ltd. (Tianjin, China).

\subsection{General Experimental Procedures}

Optical rotations were measured on a P1020 digital polarimeter (Jasco International Co. Ltd., Tokyo, Japan). UV data were recorded using a Jasco V-550 UV/Vis spectrometer. IR data were recorded on a Jasco FT/IR-480 plus spectrometer. ECD spectrum was recorded on a Jasco J-810 spectrophotometer using $\mathrm{MeOH}$ as the solvent. The ESI-MS spectra were recorded on a Finnigan LCQ Advantage MAX mass spectrometer (Thermo Fisher Scientific, Inc., Waltham, MA, USA). The HR-ESI-MS spectra were obtained on a Micromass Q-TOF mass spectrometer (Waters Corporation, Milford, MA, USA). The NMR spectra were measured with Bruker AV-400 and Bruker AV-600 spectrometers (Bruker BioSpin Group, Faellanden, Switzerland) using the solvent signals $\left(\mathrm{CDCl}_{3}\right.$ : $\left.\delta_{\mathrm{H}} 7.26 / \delta_{\mathrm{C}} 77.0\right)$ as internal standard. The analytical HPLC was performed on a Dionex HPLC system equipped with an Ultimate 3000 pump, an Ultimate 3000 diode array detector (DAD), an Ultimate 3000 Column Compartment, an Ultimate 3000 autosampler (Thermo Fisher Scientific, Inc.) using a Gemini $\mathrm{C}_{18}$ column $(4.6 \mathrm{~mm} \times 250 \mathrm{~mm}, 5 \mu \mathrm{m})$ (Phenomenex Inc., Los Angeles, CA, USA). The semi-preparative HPLC was performed on a Shimadzu LC-6-AD Liquid Chromatography with an SPD-20A Detector using a Phenomenex Gemini $C_{18}$ column (Phenomenex Inc.) $(10.0 \mathrm{~mm} \times 250 \mathrm{~mm}, 5 \mu \mathrm{m})$. The chiral HPLC was performed on a Shimadzu LC-6-AD Liquid Chromatography with an SPD-20A Detector using a Phenomenex Lux Cellulose-2 chiral column $(4.6 \mathrm{~mm} \times 250 \mathrm{~mm}, 3 \mu \mathrm{m})$. 


\subsection{Fungus Material}

The strain AHK07-3 was isolated from the soil, collected at the wetland of Ahongkou, Sinkiang Province, China. The strain was identified as Talaromyces flavus based on the morphological characters and gene sequence analysis. The ribosomal internal transcribed spacer (ITS) and the 5.8S rRNA gene sequences (ITS1-5.8S-ITS2) of the strain have been deposited at GenBank as KX011167. The fungus was cultured on slants of potato dextrose agar at $25{ }^{\circ} \mathrm{C}$ for 5 days. Agar plugs were used to inoculate four Erlenmeyer flasks $(250 \mathrm{~mL})$, each containing $100 \mathrm{~mL}$ of potato dextrose broth. Four flasks of the inoculated media were incubated at $25^{\circ} \mathrm{C}$ on a rotary shaker at $200 \mathrm{rpm}$ for 5 days to prepare the seed culture. Fermentation was carried out in 20 Erlenmeyer flasks $(500 \mathrm{~mL})$, each containing $70 \mathrm{~g}$ of rice. Distilled $\mathrm{H}_{2} \mathrm{O}(105 \mathrm{~mL})$ was added to each flask, and the rice was soaked overnight before autoclaving at $120^{\circ} \mathrm{C}$ for $30 \mathrm{~min}$. After cooling to room temperature, each flask was inoculated with $5.0 \mathrm{~mL}$ of the seed culture containing mycelia and incubated at room temperature for 50 days.

\subsection{Extraction and Isolation}

The culture was extracted with EtOAc $(3 \times 5000 \mathrm{~mL})$. Removal of EtOAc under reduced pressure yielded a crude extract $(19.7 \mathrm{~g})$ that was dissolved in $90 \% \mathrm{v} / v$ aqueous $\mathrm{MeOH}(400 \mathrm{~mL})$. The methanolic solution was further extracted with cyclohexane $(400 \mathrm{~mL})$ to afford a cyclohexane fraction C (4.6 g). Fraction C was subjected to silica gel (200-300 mesh) column chromatography initially eluting with cyclohexane $(500 \mathrm{~mL})$ and then with $\mathrm{MeOH}(500 \mathrm{~mL})$ to afford subfractions CC and CM. Subfraction CC (3.3 g) was further separated by open silica gel column chromatography eluting with cyclohexane-EtOAc (100:0 (150 mL), 99:1 (150 mL), 98:2 (150 mL), 97:3 (150 mL), $96: 4$ (150 mL), 95:5 (150 mL), 94:6 (150 mL), 93:7 (150 mL), 92:8 (150 mL), 91:9 (150 mL), 90:10 (150 mL), 50:50 (150 mL), and 0:100 (150 mL), $v / v)$ to yield four sub-subfractions (CC1 to CC4). Sub-subfraction CC2 (2.8 g) was subjected to open silica gel column chromatography eluting with PE (petroleum ether)-EtOAc (100:0 (100 mL), 99:1 (100 mL), 98:2 (100 mL), 97:3 (100 mL), 96:4 (100 mL), 95:5 (100 mL), 94:6 (100 mL), 93:7 (100 mL), 92:8 (100 mL), 91:9 (100 mL), 90:10 (100 mL), 50:50 (100 mL) and 0:100 $(100 \mathrm{~mL}), v / v)$ to yield four sub-subfractions (CC2a to CC2d). Sub-subfraction CC2b (1.1 g) was isolated by semi-preparative HPLC purification using $\mathrm{MeOH}-\mathrm{H}_{2} \mathrm{O}(88: 12, v / v)$ at a flow rate of $3 \mathrm{~mL} / \mathrm{min}$ to yield $1(617.4 \mathrm{mg}), 2(2.6 \mathrm{mg})$, and $3(24.7 \mathrm{mg})$. Sub-subfraction CC2c $(0.6 \mathrm{~g})$ was purified by semi-preparative HPLC purification using $\mathrm{MeOH}-\mathrm{H}_{2} \mathrm{O}(90: 10, v / v)$ at a flow rate of $3 \mathrm{~mL} / \mathrm{min}$ to yield $6(1.1 \mathrm{mg})$. Sub-subfraction CC4 $(220.1 \mathrm{mg})$ was isolated by semi-preparative HPLC purification using $\mathrm{MeOH}-\mathrm{H}_{2} \mathrm{O}(80: 20, v / v)$ at a flow rate of $3 \mathrm{~mL} / \mathrm{min}$ to yield the mixtures of 4 and $5(12.5 \mathrm{mg})$. Enantioseparation of 1-3 was carried out on a Phenomenex Lux Cellulose-2 chiral column using $\mathrm{CH}_{3} \mathrm{OH} / \mathrm{H}_{2} \mathrm{O}(88 / 12, v / v)$ as mobile phase.

\subsection{Spectroscopic Data of Isolated Compounds}

(土)-Arugosin K (1): yellow solid; UV (MeOH) $\lambda_{\max }(\log \varepsilon) 205$ (3.75), 221 (3.63), 304 (3.35), 359 (3.29) nm; IR (KBr) $v_{\max } 3438,2920,1708,1619,1590,1421,1206,1052 \mathrm{~cm}^{-1}$; ESI-MS (positive): $\mathrm{m} / z 355$ $[\mathrm{M}+\mathrm{H}]^{+}$, ESI-MS (negative): $m / z 353[\mathrm{M}-\mathrm{H}]^{-}$; HRESIMS (positive) $m / z 355.1550[\mathrm{M}+\mathrm{H}]^{+}$(calcd . for $\left.\mathrm{C}_{21} \mathrm{H}_{23} \mathrm{O}_{5}, 355.1545\right) ;{ }^{1} \mathrm{H}$ - and ${ }^{13} \mathrm{C}-\mathrm{NMR}$ data see Table 1.

(+)-S-Arugosin K (1a): $[\alpha]_{\mathrm{D}}^{27}+27.8\left(\right.$ c 0.5, $\left.\mathrm{CHCl}_{3}\right) ; \mathrm{ECD}\left(\right.$ c $\left.8.5 \times 10^{-5} \mathrm{M}, \mathrm{MeOH}\right) \lambda_{\max }(\Delta \varepsilon) 208(+12.50)$, $294(-5.71), 334(+3.76), 382(-1.77) \mathrm{nm}$.

(-)-R-Arugosin K (1b): $[\alpha]_{\mathrm{D}}^{27}-27.0\left(\right.$ c 0.5, $\left.\mathrm{CHCl}_{3}\right)$; ECD $\left(c 8.5 \times 10^{-5} \mathrm{M}, \mathrm{MeOH}\right) \lambda_{\max }(\Delta \varepsilon) 208(-11.38)$, $295(+6.96), 334(-3.88), 382(+2.82) \mathrm{nm}$.

(土)-Arugosin L (2): yellow solid; UV (MeOH) $\lambda_{\max }(\log \varepsilon) 206$ (3.70), 222 (3.57), 304 (3.30), 359 (3.23) nm; IR (KBr) $v_{\max } 3440,2916,1624,1590,1422,1206,1057 \mathrm{~cm}^{-1}$; ESI-MS (positive): $m / z 369[\mathrm{M}+\mathrm{H}]^{+}$; ESI-MS (negative): $m / z 367[\mathrm{M}-\mathrm{H}]^{-}$; HRESIMS (positive) $m / z 369.1695[\mathrm{M}+\mathrm{H}]^{+}$(calcd. for $\left.\mathrm{C}_{22} \mathrm{H}_{25} \mathrm{O}_{5}, 369.1702\right) ;{ }^{1} \mathrm{H}$ - and ${ }^{13} \mathrm{C}-\mathrm{NMR}$ data see Table 1. 
(+)-S-Arugosin L (2a): $[\alpha]_{\mathrm{D}}^{27}+27.4\left(\right.$ c $\left.0.5, \mathrm{CHCl}_{3}\right) ; \operatorname{ECD}\left(c 6.8 \times 10^{-5} \mathrm{M}, \mathrm{MeOH}\right) \lambda_{\max }(\Delta \varepsilon) 208(+13.90)$, $295(-6.07), 335(+5.07), 382(-1.91) \mathrm{nm}$.

(-)-R-Arugosin L (2b): $[\alpha]_{\mathrm{D}}^{27}-26.8\left(\right.$ c 0.5, $\left.\mathrm{CHCl}_{3}\right) ; \mathrm{ECD}\left(c 6.8 \times 10^{-5} \mathrm{M}, \mathrm{MeOH}\right) \lambda_{\max }(\Delta \varepsilon) 208(-13.79)$, $295(+7.98), 335(-3.44), 382(+3.40) \mathrm{nm}$.

( \pm )-Arugosin M (3): yellow solid; UV (MeOH) $\lambda_{\max }(\log \varepsilon) 206$ (3.85), 221 (3.73), 299 (3.42), 357 (3.36) nm; IR (KBr) $v_{\max } 3441,2913,1620,1464,1202,1050 \mathrm{~cm}^{-1}$; ESI-MS (positive): $m / z 355[\mathrm{M}+\mathrm{H}]^{+}$, ESI-MS (negative): $m / z 353[\mathrm{M}-\mathrm{H}]^{-}$; HRESIMS (positive) $m / z 355.1541[\mathrm{M}+\mathrm{H}]^{+}$(calcd. for $\mathrm{C}_{21} \mathrm{H}_{23} \mathrm{O}_{5}$, 355.1545); ${ }^{1} \mathrm{H}-$ and ${ }^{13} \mathrm{C}-\mathrm{NMR}$ data see Table 1.

(+)-S-Arugosin M (3a): $[\alpha]_{\mathrm{D}}^{27}+28.4\left(c 0.5, \mathrm{CHCl}_{3}\right) ; \mathrm{ECD}\left(c 8.5 \times 10^{-5} \mathrm{M}, \mathrm{MeOH}\right) \lambda_{\max }(\Delta \varepsilon) 209(+14.24)$, $290(-6.29), 334(+6.67), 381(-3.30) \mathrm{nm}$.

(-)-R-Arugosin M (3b): $[\alpha]_{\mathrm{D}}^{27}-27.6\left(c 0.5, \mathrm{CHCl}_{3}\right) ; \mathrm{ECD}\left(c 8.5 \times 10^{-5} \mathrm{M}, \mathrm{MeOH}\right) \lambda_{\max }(\Delta \varepsilon) 209(-12.84)$, $292(+7.26), 334(-5.93), 381(+4.27) \mathrm{nm}$.

Arugosin N (4): 1,6,10-trihydroxy-8-methyl-2-(3-methyl-2-butenyl)-dibenz[b,e]oxepin-11(6H)-one (5): yellow solid; UV (MeOH) $\lambda_{\max }(\log \varepsilon) 206$ (3.75), 222 (3.65), 286 (3.29), 356 (3.16) nm; IR (KBr) $v_{\max }$ $3443,2917,1628,1589,1420,1353,1173,1052 \mathrm{~cm}^{-1}$; ESI-MS (positive): $m / z 341[\mathrm{M}+\mathrm{H}]^{+}, m / z 363$ $[\mathrm{M}+\mathrm{Na}]^{+}$; ESI-MS (negative): $m / z 339[\mathrm{M}-\mathrm{H}]^{-} ;$HRESIMS (positive) $m / z 363.1213[\mathrm{M}+\mathrm{Na}]^{+}$(calcd. for $\left.\mathrm{C}_{20} \mathrm{H}_{20} \mathrm{O}_{5} \mathrm{Na}, 363.1208\right) ;{ }^{1} \mathrm{H}$ - and ${ }^{13} \mathrm{C}-\mathrm{NMR}$ data see Table 2 .

\subsection{ECD Calculation}

Before molecular initial 3D structures were generated with CORINA version 3.4 (Molecular Networks GmbH, Erlangen, Germany), the molecules of (5S)-1, (5R)-1, (5S)-3, and (5R)-3 were converted into SMILES codes, respectively. Conformer databases were generated in CONFLEX version 7.0 (CONFLEX Corporation, Tokyo, Japan) using the MMFF94s force-field, with an energy window for acceptable conformers (ewindow) of $5 \mathrm{kcal} \cdot \mathrm{mol}^{-1}$ above the ground state, a maximum number of conformations per molecule (maxconfs) of 100, and an RMSD cutoff (rmsd) of $0.5 \AA$. Then each conformer of the acceptable conformers was optimized with HF/6-31G(d) method in Gaussian09 [19]. Further optimization at the APFD/6-31G(d) level led the dihedral angles to be got. After that, eight lowest energy conformers of (5S)-1 and (5R)-1 (see Supplementary Materials Table S6 and Figure S3) were found out. Six lowest energy conformers of (5S)-3 and (5R)-3 (see Supplementary Materials Table S7 and Figure S4) were found out. The optimized conformers were taken for the ECD calculations, which were performed with Gaussian09 (APFD/6-311++G(2d,p)). The solvent effect was taken into account by the polarizable-conductor calculation model (IEFPCM, methanol as the solvent). Comparisons of the experimental and calculated spectra were done with the software SpecDis $[20,21]$. It was also used to apply a UV shift to the ECD spectra, Gaussian broadening of the excitations, and Boltzmann weighting of the spectra.

\section{Conclusions}

Up to now, about nine isopentenyl dibenzo[b,e]oxepinones with intact 6-7-6 tricyclic systems have been reported from the genera of Aspergillus, Emericella, Pestalotiopsis, Graphiopsis, and Penicilium. Except the absolute configuration of cephalanone D that had been verified by X-ray crystallography [6], the absolute configurations of the others had not been not investigated. In our study, the absolute configurations of the three pairs of enantiomers $((+)-(5 S)-\mathbf{1 a},(-)-(5 R)-\mathbf{1} \mathbf{b}$, $(+)-(5 S)-\mathbf{2} \mathbf{a},(-)-(5 R)-\mathbf{2} \mathbf{b},(+)-(5 S)-\mathbf{3} \mathbf{a},(-)-(5 R)-3 \mathbf{b})$, isolated for the first time from the genus Talaromyces, were determined by quantum chemical ECD calculations, which is the first report for the absolute configuration of isopentenyl dibenzo[b,e]oxepinones established by ECD experiments. Furthermore, 1,6,10-trihydroxy-8-methyl-2-(3-methyl-2-butenyl)-dibenz[b,e]oxepin-11(6H)-one (5) is a known compound, but no NMR data was previously reported. The assignments of NMR data of 5 are thus provided for the first time. 
Supplementary Materials: The following are available online at http://www.mdpi.com/1420-3049/21/9/1184/ s1, The 1D and 2D NMR data of 1-5, and quantum chemical ECD calculations of $\mathbf{1}$ and 3.

Acknowledgments: This work was financially supported by grants from the National Natural Science Foundation of China (81422054 and 81373306), the Guangdong Natural Science Funds for Distinguished Young Scholar (S2013050014287), Guangdong Special Support Program (2014TQ01R420), Guangdong Province Universities and Colleges Pearl River Scholar Funded Scheme (Hao Gao, 2014), Pearl River Nova Program of Guangzhou (201610010021), K.C.Wong Education Foundation (Hao Gao, 2016), and the high-performance computing platform of Jinan University.

Author Contributions: Hao Gao and Xin-Sheng Yao initiated and coordinated the project. Hao Gao and Guo-Dong Chen wrote this paper. Tian-Yu Sun and Run-Qiao Kuang performed the extraction, isolation, and structural identification of the compounds. Sheng-Ying Qin and Chuan-Xi Wang performed the fermentation of the fungal strain (AHK07-3). Xing-Zhong Liu, Bin Wu, and Dan Hu performed the isolation and identification of the fungal strain (AHK07-3).

Conflicts of Interest: The authors declare no conflict of interest.

\section{References}

1. Ballantine, J.; Francis, D.; Hassall, C.; Wright, J. The biosynthesis of phenols. Part XXI. The molecular structure of arugosin, a metabolite of a wild-type strain of Aspergillus rugulosus. J. Chem. Soc. C 1970, 9, 1175-1182. [CrossRef]

2. Ballantine, J.; Ferrito, V.; Hassall, C.; Jenkins, M. Biosynthesis of phenols. Part XXIV. Arugosin C, a metabolite of a mutant strain of Aspergillus rugulosus. J. Chem. Soc. Perkin Trans. 1 1973, 17, 1825-1830. [CrossRef] [PubMed]

3. Chexal, K.; Holker, J.; Simpson, T. Biosynthesis of fungal metabolites. Part VI. Structures and biosynthesis of minor metabolites from variant strains of Aspergillus variecolor. J. Chem. Soc. Perkin Trans. 1 1975, 6, 549-554. [CrossRef] [PubMed]

4. Kralj, A.; Kehraus, S.; Krick, A.; Eguereva, E.; Kelter, G.; Maurer, M.; Wortmann, A.; Fiebig, H.; Koenig, G. Arugosins $\mathrm{G}$ and $\mathrm{H}$ : Prenylated polyketides from the narine-derived fungus Emericella nidulans var. acristata. J. Nat. Prod. 2006, 69, 995-1000. [CrossRef] [PubMed]

5. Li, E.; Jiang, L.; Guo, L.; Zhang, H.; Che, Y. Pestalachlorides A-C, antifungal metabolites from the plant endophytic fungus Pestalotiopsis adusta. Bioorg. Med. Chem. 2008, 16, 7894-7899. [CrossRef] [PubMed]

6. Asai, T.; Otsuki, S.; Sakurai, H.; Yamashita, K.; Ozeki, T.; Oshima, Y. Benzophenones from an Endophytic Fungus, Graphiopsis chlorocephala, from Paeonia lactiflora Cultivated in the Presence of an NAD ${ }^{+}$-Dependent HDAC Inhibitor. Org. Lett. 2013, 15, 2058-2061. [CrossRef] [PubMed]

7. Mizogami, K.; Kyo, A.; Nakaike, S.; Ikeda, T.; Hanada, K. Preparation of Dihydrodibenzoxepinone Derivative as Antitumor Agent. JP 06271561A, 27 September 1994.

8. Proksa, B. Talaromyces flavus and its metabolites. Chem. Pap. 2010, 64, 696-714. [CrossRef]

9. Li, H.; Huang, H.; Shao, C.; Huang, H.; Jiang, J.; Zhu, X.; Liu, Y.; Liu, L.; Lu, Y.; Li, M.; et al. Cytotoxic norsesquiterpene peroxides from the endophytic fungus Talaromyces flavus isolated from the mangrove plant Sonneratia apetala. J. Nat. Prod. 2011, 74, 1230-1235. [CrossRef] [PubMed]

10. Bao, Y.; Chen, G.; Wu, Y.; Li, X.; Hu, D.; Liu, X.; Li, Y.; Yao, X.; Gao, H. Stachybisbins A and B, the first cases of seco-bisabosquals from Stachybotrys bisbyi. Fitoterapia 2015, 105, 151-155. [CrossRef] [PubMed]

11. Bao, Y.; Chen, G.; Gao, H.; He, R.; Wu, Y.; Li, X.; Hu, D.; Wang, C.; Liu, X.; Li, Y.; et al. 4,5-seco-Probotryenols A-C, a new type of sesquiterpenoids from Stachybotrys bisbyi. RSC Adv. 2015, 5, 46252-46259. [CrossRef]

12. He, J.; Mu, Z.; Gao, H.; Chen, G.; Zhao, Q.; Hu, D.; Sun, J.; Li, X.; Li, Y.; Liu, X.; et al. New polyesters from Talaromyces flavus. Tetrahedron 2014, 70, 4425-4430. [CrossRef]

13. He, J.; Qin, D.; Gao, H.; Kuang, R.; Yu, Y.; Liu, X.; Yao, X. Two new coumarins from Talaromyces flavus. Molecules 2014, 19, 20880-20887. [CrossRef] [PubMed]

14. He, J.; Liang, H.; Gao, H.; Kuang, R.; Chen, G.; Hu, D.; Wang, C.; Liu, X.; Li, Y.; Yao, X. Talaflavuterpenoid A, a new nardosinane-type sesquiterpene from Talaromyces flavus. J. Asian Nat. Prod. Res. 2014, 16, 1029-1034. [CrossRef] [PubMed]

15. Sun, T.; Zou, J.; Chen, G.; Hu, D.; Wu, B.; Liu, X.; Yao, X.; Gao, H. A Set of Interesting Sequoiatone Stereoisomers from a Wetland Soil-Derived Fungus Talaromyces flavus. Acta Pharm. Sin. B 2016. [CrossRef]

16. Danielsen, K.; Aksnes, D. NMR study of some anthraquinones from rhubarb. Magn. Reson. Chem. 1992, 30, 359-360. [CrossRef] 
17. Pockrandt, D.; Ludwig, L.; Fan, A.; Koenig, G.; Li, S. New Insights into the Biosynthesis of Prenylated Xanthones: Xptb from Aspergillus nidulans Catalyses an O-Prenylation of Xanthones. ChemBioChem 2012, 13, 2764-2771. [CrossRef] [PubMed]

18. Simpson, T. Genetic and biosynthetic studies of the fungal prenylated xanthone shamixanthone and related metabolites in Aspergillus spp. revisited. ChemBioChem 2012, 13, 1680-1688. [CrossRef] [PubMed]

19. Frisch, M.; Trucks, G.; Schlegel, H.; Scuseria, G.; Robb, M.; Cheeseman, J. Gaussian 09 Revision D.01; Gaussian Inc.: Wallingford, CT, USA, 2010.

20. Bruhn, T.; Schaumlöffel, A.; Hemberger, Y.; Bringmann, G. Version 1.61; University of Würzburg: Würzburg, Germany, 2013.

21. Bruhn, T.; Schaumlöffel, A.; Hemberger, Y.; Bringmann, G. SpecDics: Quantifying the comparison of calculated and experimental electronic circular dichroism spectra. Chirality 2013, 25, 243-249. [CrossRef] [PubMed]

Sample Availability: Samples of the compounds are not available from the authors.

(C) 2016 by the authors; licensee MDPI, Basel, Switzerland. This article is an open access article distributed under the terms and conditions of the Creative Commons Attribution (CC-BY) license (http://creativecommons.org/licenses/by/4.0/). 